\title{
Balkanologie
}

Balkanologie Revue d'études pluridisciplinaires

Vol. $15 n^{\circ} 1 \mid 2020$

Mémoires performatives : faire des passés et des présents

\section{Anne Madelain, L'expérience française des Balkans}

Tours, Presses Universitaires François-Rabelais, 2019

\section{Agustín Cosovschi}

\section{CpenEdition}

\section{Journals}

Electronic version

URL: https://journals.openedition.org/balkanologie/2545

DOI: 10.4000/balkanologie.2545

ISSN: 1965-0582

Publisher

Association française d'études sur les Balkans (Afebalk)

\section{Electronic reference}

Agustín Cosovschi, "Anne Madelain, L'expérience française des Balkans", Balkanologie [Online], Vol. 15 n 1 | 2020, Online since 01 June 2020, connection on 05 August 2021. URL: http://

journals.openedition.org/balkanologie/2545 ; DOI: https://doi.org/10.4000/balkanologie.2545

This text was automatically generated on 5 August 2021.

(c) Tous droits réservés 


\title{
Anne Madelain, L'expérience française des Balkans
}

\author{
Tours, Presses Universitaires François-Rabelais, 2019
}

Agustín Cosovschi

\section{REFERENCES}

Madelain, Anne, 2019, L'expérience française des Balkans, Tours, Presses Universitaires François-Rabelais, 360 pages, ISBN : 978-2-86906-704-2

1 Thirty years have passed since the dissolution of the League of Communists of Yugoslavia following its last and ill-fated congress in January 1990, an event that many would agree marked the beginning of the Yugoslav breakup. Since then, analyses of the dissolution of Yugoslavia have proliferated in several disciplines, covering the most diverse dimensions of the process and providing new insights into how it unfolded in the political, economic, social, cultural and intellectual realms. A similar observation can be made generally about the end of communism in the remainder of Eastern Europe, the object of a long tradition of scholarship since the early 1990s. As a result, it is certainly hard to offer new insights on these events. And yet, by examining the repercussions that the end of communism in Romania and Yugoslavia had among the French public, and by offering a perspective that combines national and transnational approaches with a rich theoretical frame, Anne Madelain's book L'expérience française des Balkans succeeds in illuminating new aspects of these processes, simultaneously shedding light on the transformations of French politics and society after the fall of the Berlin Wall.

In this rather recent book based on her doctoral dissertation, Anne Madelain sets out to investigate the reactions and repercussions that events in the Balkans after the fall of communism had among the French public, focusing on responses to the Romanian crisis of the late 1980s and to the Yugoslav wars of the 1990s. Drawing from a rich theoretical apparatus that includes, among others, Reinhart Koselleck's notions of 
experience and temporality and Erving Goffman's sociology of perceptions, the author claims that the events that unfolded in the Balkans in the early 1990s triggered a process that may be conceptualized as a French experience: a turning point in French perceptions, concepts, political repertoires and images concerning the Balkans.

Drawing from a vast and diverse corpus of written and oral sources that includes print and visual media, oral testimonies, intellectual and literary sources and archival sources from citizens' associations involved in antiwar initiatives, Anne Madelain examines in detail the reactions that both the Romanian crisis and the Yugoslav wars provoked in France. This includes broad and diverse forms of citizens' activism, strong interventions by public intellectuals, manifold cultural and artistic campaigns of international solidarity, and even frustrated attempts in electoral politics. The author undertakes this task with great competence. She offers a critical approach of the moralizing and often apolitical overtones of the humanitarian discourse, as well as a critical appraisal of the ever-growing influence of the media and the effects of its spectacularization of war and tragedy on social perceptions. The author's analysis is at times sharply critical: by showing the frequent misunderstandings and oversimplifications to which many activists fell prey due to their lack of deeper acquaintance with the Balkans, the author shows the haunting risks of engaging politically with events taking part in distant and unknown geographies. Moreover, she analyzes these phenomena under the light of the longer history of French political and intellectual conceptions and perceptions about the Balkans since the nineteenth century. All in all, the book not only offers interesting insights about the international repercussions of the crises in the Balkans, but it also illuminates the political, social and intellectual transformations of French society and politics at the end of the Cold War.

In many senses, the analysis transpires from the author's own personal experience as a foreigner living in the former Yugoslavia and Romania throughout the 1990s. This allows her to combine a thorough knowledge of the complexities of the region with a clear awareness of the difficulties of translating Balkan history and politics into French categories. In that sense, one of the central claims of the book, that the crises in the Balkans brought a "rupture of intelligibility" in France - namely a realization that the traditional post-1945 structures of perception and means of political action were inadequate to frame current developments after the fall of communism - is perhaps grounded not only on scientific analysis, but also on personal experience.

5 In a more critical vein, it can be noted that the book gives an uneven importance to the Romanian and Yugoslav crises. Although the Romanian crisis occurred first, with the events in Timișoara portrayed as having a key impact on French perceptions of the post-communist Balkans, it is given less attention overall than are the developments in Yugoslavia. It is thus reasonable to question the necessity of the Balkan framework adopted by the author, and to speculate in turn on the potential benefits of focusing this study exclusively on the Yugoslav crisis.

6 These observations notwithstanding, Anne Madelain's L'expérience française des Balkans offers an original and illuminating analysis of processes taking place both in Eastern and Western Europe in the early 1990s, as well as a thoughtful and sharp critique of the repertoires of political action under the aegis of humanitarianism. Complementarily, the fact that the book is written in French, a language that has so far remained secondary in scholarship about the Balkans, constitutes an auspicious sign for the future development of Eastern European studies. It also increases the book's potential 
for reaching new audiences, including perhaps many of those who found themselves affected and moved by the vivid events taking place in the Balkans in the 1990s.

INDEX

Geographical index: Balkans, France, Yougoslavie, Roumanie

\section{AUTHORS}

AGUSTÍN COSOVSCHI

CETOBaC, Paris 